\title{
Assessment of Risk Factors for Lymph Node Metastasis in Endometrial Cancer
}

\author{
Endometriyum Kanserinde Lenf Nodu Metastazı için Risk Faktörlerinin \\ Değerlendirilmesi
}

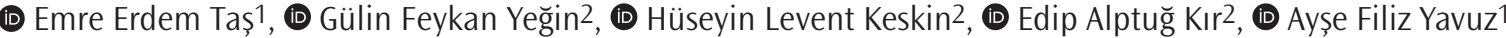 \\ ${ }^{1}$ Ankara Yıldırım Beyazıt University Faculty of Medicine, Department of Obstetrics and Gynecology, Ankara, Turkey \\ ${ }^{2}$ Ankara Atatürk Training and Research Hospital, Clinic of Obstetrics and Gynecology, Ankara, Turkey
}

\begin{abstract}
Introduction: To determine the clinical and pathologic factors that are risk factors for metastasis of the lymph nodes (pelvic and/or aortic lymph nodes) in cases who underwent staging surgery due to endometrial carcinoma.

Methods: The clinical and pathological characteristics of 143 patients who underwent staging surgery between 2007 and 2016 were retrospectively analyzed. Linear regression analysis, logistic regression analysis, Spearman correlation and Receiver operator curve tests were used to determine risk factors for lymph node metastasis. $\mathrm{P}<0.05$ was considered significant in all statistical evaluations.
\end{abstract}

Results: Thirteen cases (9.1\%) had lymph node metastasis [5 cases (3.5\%) only pelvic, 3 cases $(2.1 \%)$ only paraaortic, 5 cases (3.5\%) both pelvic and paraaortic lymph node]. In linear regression analysis, there was a significant correlation between lymph node metastasis and non-endometrioid histological type, deep myometrial invasion ( $\geq 50 \%$ invasion depth), advanced histologic grade, lymphovascular space invasion, positive peritoneal cytology and tumor size $(p<0.05)$. The correlation between tumor size and lymph node metastasis was positive, and Receiver operator curve revealed $4.25 \mathrm{~cm}$ tumor size was the most appropriate cut-off value for risk of lymph node metastasis (sensitivity $=83 \%$, specificity $=75 \%$ ). In logistic regression analysis, lymphovascular space invasion was the only independent risk factor for nodal metastasis (odss ratio: 11.8; 95\% confidence interval: 1.8-75.4, $p=0.009$ ).

Conclusion: In endometrial cancer cases, lymphovascular space invasion is the only independent risk factor for lymph node metastasis. There is linear correlation between tumor size and lymph node metastasis. Further studies is needed to determine the limit value of tumor size for lymph node metastasis.

Keywords: Endometrial carcinoma, lymphatic metastasis, logistic model

\section{öZ}

Amaç: Endometriyum kanseri nedeni ile evreleme operasyonu yapılan olgularda lenf nodu (pelvik ve/veya paraaortik lenf nodları) metastazı için risk oluşturan klinik ve patolojik faktörlerin belirlenmesidir.

Yöntemler: Çalıșmamızda 2007-2016 yılları arasında endometriyum kanseri tanısı ile evreleme cerrahisi uygulanan 143 olgunun klinik ve patolojik özellikleri retrospektif olarak incelendi. Lenf nodu metastazı için risk faktörlerinin belirlenmesinde doğrusal regresyon analizi, lojistik regresyon analizi, Spearman korelasyon testi ve işlem karakteristik eğrisi testleri kullanıldı. Tüm istatistiksel değerlendirmeler için $\mathrm{p}<0,05$ anlamlı kabul edildi.

Bulgular: Beş olguda $(\% 3,5)$ sadece pelvik, 3 olguda $(\% 2,1)$ sadece paraaortik, 5 olguda $(\% 3,5)$ ise hem pelvik hem de paraaortik lenf nodu olmak üzere 13 olguda $(\% 9,1)$ lenf nodu metastazı mevcuttu. Doğrusal regresyon analizinde non-endometrioid histolojik tip, derin miyometrial invazyon ( $\geq \% 50$ invazyon derinliği), ileri histolojik grade, lenfovasküler alan invazyonu, pozitif peritoneal sitoloji ve tümör boyutu ile lenf nodu metastazı arasında anlamlı ilişki bulundu $(p<0,05)$. Tümör boyutu ile lenf nodu metastazı arasında pozitif korelasyon mevcuttu ve ișlem karakteristik eğrisinde 4,25 cm tümör boyutu lenf nodu metastazı için en uygun sınır değer olarak tespit edildi (duyarlılık \%83, özgüllük \%75). Regresyon analizinde ise lenfovasküler alan invazyonu lenf nodu metastazı için bağımsız tek risk faktörü olarak belirlendi (odss oranı: 11,8; \%95 güven aralı̆̆ı: 1,8-75,4; $p=0,009$ ).

Sonuç: Endometriyal kanserli olgularda lenfovasküler alan invazyonu lenf nodu metastazı için bağımsız tek risk faktörüdür. Tümör boyutu ile lenf nodu metastazı arasındaki korelasyon ise doğrusaldır. Lenf nodu metastazı için tümör boyutunun sınır değerini belirlemede yeni çalıșmalara ihtiyaç vardır.

Anahtar Kelimeler: Endometriyal karsinoma, lenfatik metastaz, lojistik model
Address for Correspondence/Yazıșma Adresi: Emre Erdem Taș, Ankara Yıldırım Beyazıt University Faculty of Medicine, Department of Obstetrics and Gynecology, Ankara, Turkey

Phone: +90 5066035777 E-mail: doctortas@yahoo.com ORCID ID: orcid.org/0000-0001-6043-2700

Cite this article as/Atıf: Taș EE, Yeğin Akçay GF, Keskin HL, Kır EA, Yavuz AF. Assessment of Risk Factors for Lymph Node Metastasis in Endometrial Cancer. İstanbul Med J 2019; 20(1): 8-12.
Received/Geliș Tarihi: 23.11.2017 Accepted/Kabul Tarihi: 24.05.2018

(c) Copyright 2019 by the Istanbul Training and Research Hospital/istanbul Medical Journal published by Galenos Publishing House.

(C) Telif Hakkı 2019 Istanbul Ĕgitim ve Araștırma Hastanesi/Istanbul Tıp Dergisi, Galenos Yayınevi tarafından basılmıștır. 


\section{Introduction}

Endometrial cancer (EC) is the most common type of gynecologic cancer in Turkey and in other developed countries (9.8/100,000 and $14.7 / 100,000$, respectively), and it is the second most common type of gynecologic cancer in developing countries (5.5/100.000) (1,2). Compared with other gynecologic cancers, patients with EC are diagnosed at an earlier stage (approximately $75 \%$ of cases), thus having a better prognosis (1). However, the incidence of endometrial cancer is increasing in both developed and developing countries due to increasing risk factors such as high frequency of obesity, prolonged lifetime expectancy and decreased parity (2-4).

The staging of patients diagnosed with EC has been performed surgically since 1988 according to the recommendation of the "International Federation of Gynecology and Obstetrics (FIGO)" (5). FIGO surgical staging is accepted as the most important prognostic factor in these tumors. Apart from the surgical staging, age of the patient, tumor characteristics [histology, grade, size, degree of myometrial invasion, lymphovascular space invasion (LVSI)], peritoneal cytology, and lymph node (LN) involvement also have prognostic significance (3). Among these, $L N$ involvement is also important in initiating postoperative adjuvant treatment and also in determining radiotherapy area.

Currently, there is no definite method to detect the presence of LN metastases preoperatively or intraoperatively (6-11). For this reason, FIGO and "American Congress of Obstetricians and Gynecologists" recommend performing both pelvic and paraaortic LN sampling in surgical staging of patients with EC (12). However, there is no consensus on the extent of LN sampling area (13). On the other hand, it is accepted that the risk of LN metastasis increases in the presence of various risk factors, such as non-endometrioid histology, advanced histological grade, deep myometrial invasion, LVSI, and high preoperative serum tumor marker levels (cancer antigen 125 and 15-3) (6-8,14-16) and it is recommended to keep the LN sampling area as wide as possible (17).

In this study, we aimed to determine the risk factors for LN metastasis by examining the clinical and surgical characteristics of the patients who underwent surgical staging for EC and to compare the results with similar studies.

\section{Methods}

\section{Patient Selection and Evaluation}

Following approval of the local ethics committee (Ankara Yıldırım Beyazit University Faculty of Medicine Ethics Committee acceptance no: 26379996/210), the patients who underwent surgical staging for EC between 2007 and 2016 at Ankara Yıldırım Beyazit University Ankara Ataturk Training and Research Hospital were retrospectively evaluated. Since our study was a retrospective case-control study, "informed consent form" was not obtained from the patients. The study was conducted in accordance with the ethical standards defined in the 1964 Helsinki declaration and its later amendments.

Clinical [age, gravida, parity and menopause status (yes or no)] and pathological features [FIGO surgical staging, histology (endometrioid or non-endometrioid), grade (low (grade I-II) or high (grade III)], tumor size (cm), degree of myometrial invasion ( $<1 / 2$ or $\geq 1 / 2$ ), LVSI (yes or no), peritoneal cytology, and LN sampling results (positive or negative) of all patients were recorded. The data were obtained from the patient files and hospital information system. Patients with incomplete surgical staging according to the FIGO recommendation (18), less than 20 harvested LNs (19), pre-operative neo-adjuvant therapy (hormone therapy, chemotherapy or radiotherapy), concurrent gynecologic malignant tumor diagnosis and mixed type histology were excluded from the study. The clinical and surgical features of the patients who were staged before 2009 were reviewed and their new stages were determined according to the recently published FIGO system (FIGO-2) (20). Then the patients were divided into two groups according to $L N$ metastasis, and the parameters that constitute risk for LN metastasis were evaluated. We tried to determine the independent risk factors among parameters that were different between groups.

\section{Statistical Analysis}

Statistical analysis was performed using Statistical Package for the Social Sciences (SPSS) ver. 21.0 (IBM Corp., Armonk, NY, US). KolmogorovSmirnov test was used to determine the normality of the data. The data with normal distribution were expressed as mean \pm standard deviation (range) and data without normal distribution were expressed as median (interquartile range) (range). Linear regression analysis was used to determine the risk factors for LN metastasis and logistic regression analysis was used to determine the independent risk factors. The relationship between tumor size and LN metastasis was evaluated by Spearman's correlation test. Receiver operator curve (ROC) analysis was used to determine the cutoff value for LN metastasis. Independent sample t-test and Mann-Whitney $U$ test were used to compare numerical data, and chi-square test was used to compare categorical data. $\mathrm{P}<0.05$ was considered statistically significant for all statistical analysis. Odds ratios (ORs) were determined with 95\% confidence interval (CI).

\section{Results}

A total of 154 patients underwent surgical staging for EC within the specified period. However, 11 patients who met the exclusion criteria were excluded from the study. Of 143 patients included in the study, pelvic and/or paraaortic LN metastases were detected in a total of 13 patients (9.1\%), including five cases with only pelvic (3.5\%), three cases (2.1\%) with only paraaortic, and five cases (3.5\%) with both pelvic and paraaortic LN metastasis. The distribution of all patients in the study is shown in the study flow chart (Figure 1).

The clinical and surgical features of the patients included in the study are presented in Table 1. Linear regression analysis revealed significant relationship between $\mathrm{LN}$ metastasis and non-endometrioid histology, deep myometrial invasion ( $250 \%$ invasion depth), advanced histological grade (grade III), LVSI, positive peritoneal cytology, and tumor size $(p<0.05)$ (Table 2). There was a positive correlation between tumor size and LN involvement $(p=0.001)$. In the ROC curve analysis, a $4.25 \mathrm{~cm}$ tumor size was found to be the cut-off value for LN metastasis (83\% sensitivity and $75 \%$ specificity) $(p=0.001)$ (Figure 2). In logistic regression analysis, LVSI was the only independent risk factor for LN metastasis (OR=11.8; 95\% Cl, 1.8-75.4, $\mathrm{p}=0.009)$. 


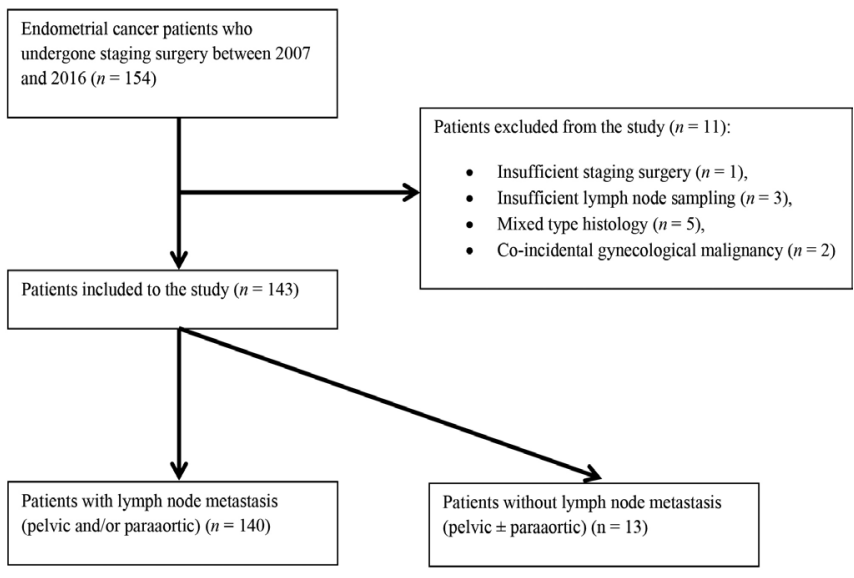

Figure 1. Flow chart of the study

Table 1. The clinical and pathological features of the patients

Features

Patients ( $n=143$ )

Age (year), mean \pm SD (range)

Gravida, median (IQR) (range)

Parity, median (IQR) (range)

Menopause status, $\mathrm{n}(\%)$

Y

N

FIGO staging, $n(\%)$

Stage IA

Stage IB

Stage II

Stage IIIA

Stage IIIB

Stage IIIC1

Stage IIIC2

Stage IVA

Stage IVB

Histology, n (\%)

Endometrioid type

Non-endometrioid type

Histological grade, $\mathrm{n}(\%)$

Low (grade I, II)

High (grade III)

Tumor size, mean \pm SD (range)

Myometrial invasion, $\mathrm{n}(\%)$

$\geq 1 / 2$

$<1 / 2$

LVSI, n (\%)

$\mathrm{Y}$

N

Positive peritoneal cytology, $\mathrm{n}(\%)$

$Y$

$\mathrm{N}$

SD: standard deviation, IQR: interquartile range, Y: yes, N: no, FIGO: Federation of Gynecology and Obstetrics, LVSI: lymphovascular space invasion

$60.3 \pm 10.2(40-85)$

4 (3) (0-16)

$3(2)(0-15)$

$113(79 \%)$

$30(21 \%)$

$91(63.6 \%)$

$29(20.3 \%)$

$8(5.6 \%)$

$1(0.7 \%)$

$4(2.8 \%)$

$5(3.5 \%)$

$2(1.4 \%)$

$2(1.4 \%)$

$120(83.9 \%)$

$23(16.1 \%)$

$116(81.1 \%)$

$27(18.9 \%)$

$3.4 \pm 2.2(0.1-12)$

$12(8.4 \%)$

$131(91.6 \%)$

$111(77.6 \%)$

$32(22.4 \%)$

$111(77.6 \%)$

$32(22.4 \%)$

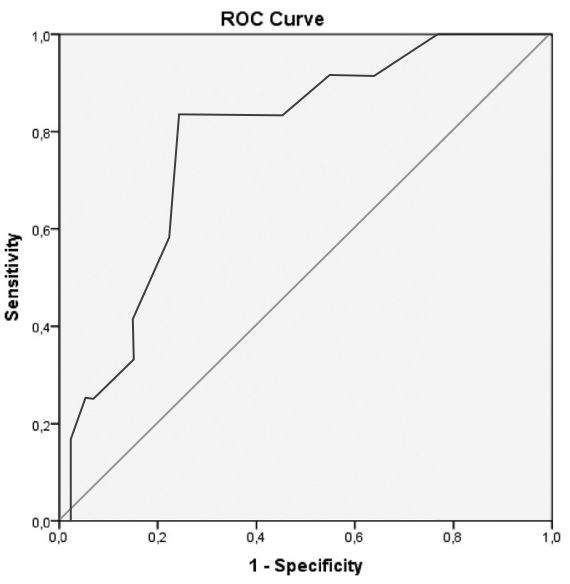

Figure 2. Receiver operator curve analysis of the relationship between tumor size and lymph node involvement in patients with endometrial cancer (area under curve $=0.78$; standard error $=0.06 ; \mathrm{p}=0.001 ; 95 \%$ confidence interval, 0.6-0.9)

$1(0.7 \%)$

10
Table 2. The comparison of clinical and pathological features of the patients with and without lymph node metastasis

\begin{tabular}{|c|c|c|c|}
\hline Features & $\begin{array}{l}\text { Patients without } \\
\text { lymph node } \\
\text { metastasis } \\
(n=130,90.9 \%)\end{array}$ & $\begin{array}{l}\text { Patients with } \\
\text { lymph node } \\
\text { metastasis } \\
(n=13,9.1 \%)\end{array}$ & $\mathbf{p}$ \\
\hline $\begin{array}{l}\text { Age (year), mean } \pm S D \\
\text { (range) }\end{array}$ & $60.1 \pm 10.5(40-85)$ & $62.1 \pm 7.9(50-77)$ & 0.49 \\
\hline $\begin{array}{l}\text { Gravida, median (IQR) } \\
\text { (range) }\end{array}$ & 4 (3) $(0-16)$ & $5(3)(0-8)$ & 0.21 \\
\hline $\begin{array}{l}\text { Parity, median (IQR) } \\
\text { (range) }\end{array}$ & $3(2)(0-15)$ & $4(3)(0-7)$ & 0.17 \\
\hline $\begin{array}{l}\text { Menopause status, n (\%) } \\
\text { Y } \\
\text { N }\end{array}$ & $\begin{array}{l}101(70.6 \%) \\
29(20.3 \%)\end{array}$ & $\begin{array}{l}12(8.4 \%) \\
1(0.7 \%)\end{array}$ & 0.3 \\
\hline $\begin{array}{l}\text { Histology, n (\%) } \\
\text { Endometrioid type } \\
\text { Non-endometrioid type }\end{array}$ & $\begin{array}{l}114(79.7 \%) \\
16(11.2 \%)\end{array}$ & $\begin{array}{l}6(4.2 \%) \\
7(4.9 \%)\end{array}$ & 0.001 \\
\hline $\begin{array}{l}\text { Histological grade, n (\%) } \\
\text { Low (grade I, II) } \\
\text { High (grade III) }\end{array}$ & $\begin{array}{l}111(77.6 \%) \\
19(13.3 \%)\end{array}$ & $\begin{array}{l}5(3.5 \%) \\
8(5.6 \%)\end{array}$ & 0.001 \\
\hline $\begin{array}{l}\text { Tumor size, mean } \pm \text { SD } \\
\text { (range) }\end{array}$ & $3.3 \pm 2.2(0.1-12)$ & $5.2 \pm 1.8(2-8)$ & 0.002 \\
\hline $\begin{array}{l}\text { Myometrial invasion, } \mathrm{n}(\%) \\
\geq 1 / 2 \\
<1 / 2\end{array}$ & $\begin{array}{l}7(4.9 \%) \\
123(86 \%)\end{array}$ & $\begin{array}{l}5(3.5 \%) \\
8(5.6 \%)\end{array}$ & 0.002 \\
\hline $\begin{array}{l}\text { LVSI, n (\%) } \\
\text { Y } \\
\text { N }\end{array}$ & $\begin{array}{l}21(14.7 \%) \\
109(76.2 \%)\end{array}$ & $\begin{array}{l}11(7.7 \%) \\
2(1.4 \%)\end{array}$ & 0.001 \\
\hline $\begin{array}{l}\text { Positive peritoneal } \\
\text { cytology, n (\%) } \\
\text { Y } \\
\text { N }\end{array}$ & $\begin{array}{l}4(2.8 \%) \\
126(88.1 \%)\end{array}$ & $\begin{array}{l}4(2.8 \%) \\
9(6.3 \%)\end{array}$ & 0.002 \\
\hline
\end{tabular}




\section{Discussion}

In patients with EC, the presence of LN metastasis significantly reduces both the disease-free survival and overall survival by half (21). LN metastasis is reported in approximately $10 \%$ of patients with EC limited to the uterus (22). In our study, LN metastasis was observed in $9.4 \%$ of all EC patients.

In studies evaluating risk factors for LN metastasis in patients with EC, the parameters that are considered as negative prognostic factors for EC are also indicated as risk factors for LN metastasis (6-8,14-16). However, there is no consistency between the results of similar studies. For example, while non-endometrioid histology, deep myometrial invasion ( $\geq 1 / 2$ myometrial invasion) and advanced histological grade (grade III) were found to be independent risk factors for LN metastasis in a Swedish study, only the number of harvested LNs (>30) was found to be an independent risk factor in another study $(6,23)$. In another study, LVSI was reported to be the only independent risk factor for LN metastasis (24). In accordance with most of similar studies, a significant relationship was found between LN metastasis and non-endometrioid histology, deep myometrial invasion ( $\geq 50 \%$ invasion depth), advanced histological grade (grade III), LVSI, positive peritoneal cytology and tumor size in our study. However, only LVSI was found to be an independent risk factor for LN metastasis.

In the studies evaluating the relationship between tumor size and LN metastasis, the consensus is that the risk of LN metastasis increases with increasing tumor size. In a pioneering study on this subject, it was reported that no LN metastasis was seen with a tumor size less than 2 $\mathrm{cm}$ and this cut-off value was suggested to be used to determine lowrisk cases for LN metastasis (25). Following this study, many studies, including SEER study, used $2 \mathrm{~cm}$ as a cut-off value when assessing risk for LN metastasis (26). However, in a recent study by Cox Bauer et al. (27) in patients with endometrioid type EC, it was shown that using $5 \mathrm{~cm}$ as the cut-off value was statistically more significant in determining the risk of LN metastasis. In our study, we found a positive correlation between tumor size and LN metastasis, and determined " $4.25 \mathrm{~cm}$ " as the cut-off value for the risk of $\mathrm{LN}$ metastasis. We found a lower cut-off value than Cox Bauer et al. (27) and this might be related to including patients with non-endometrioid type EC in our study. However, both Cox Baurer et al. (27) and we found the cut-off value that is at least two times more than recommended " $2 \mathrm{~cm}$ " cut-off value for $\mathrm{LN}$ metastasis.

\section{Study Limitations}

Our study has some limitations such as being a single-center and retrospective study. However, our results are important in terms of showing that LVSI is the most important risk factor for increased risk of LN metastasis in patients with EC, and that the risk in case of LVSI is at least 11 times higher. Therefore, the evaluation of LVSI status besides tumor histology and grade in intraoperative frozen section analysis might affect LN sampling decision in low-risk patients and LN sampling extent in high-risk patients.

\section{Conclusion}

On the other hand, our results show that the relationship between tumor size and LN metastasis needs to be re-evaluated. Further studies examining the relationship between tumor size and LN metastasis in different histological subtypes can restate the risk concept in these patients.

Ethics Committee Approval: Local ethics committee (Ankara Yıldırım Beyazit University Faculty of Medicine committee acceptance no: 26379996/210).

Informed Consent: Since our study was a retrospective case-control study, "informed consent form" was not obtained from the patients.

Peer-review: Internally peer-reviewed.

Author Contributions: Concept - E.E.T., G.F.Y.A., H.L.K., E.A.K., A.F.Y.; Design - E.E.T., G.F.Y.A., H.L.K., E.A.K., A.F.Y.; Supervision - E.E.T., G.F.Y.A., H.L.K., E.A.K., A.F.Y.; Resources - E.E.T., G.F.Y.A., E.A.K.; Materials - E.A.K.; Data Collection and/or Processing - E.E.T., G.F.Y.A., H.L.K.; Analysis and/or Interpretation - E.E.T., G.F.Y.A., A.F.Y.; Literature Search - E.E.T., G.F.Y.A.; Writing Manuscript - E.E.T.; Critical Review - H.L.K., A.F.Y.

Conflict of Interest: No conflict of interest was declared by the authors.

Financial Disclosure: The authors declared that this study received no financial support.

\section{References}

1. Torre LA, Bray F, Siegel RL, Ferlay J, Lortet-Tieulent J, Jemal A. Global cancer statistics, 2012. CA Cancer J Clin 2015; 65: 87-108.

2. T.C. Health Ministry, Turkish Public Health Agency. Turkey Cancer Statistics. [Internet]. Ankara, GA, Turkey: T.C. Sağlık Bakanlığı; 2017 [cited 2017 Oct 12]. Available from: http://kanser.gov.tr/Dosya/ca_istatistik/2014-RAPOR. uzun.pdf

3. Amant F, Moerman P, Neven P, Timmerman D, Van Limbergen E, Vergote I. Endometrial cancer. Lancet 2005; 366: 491-505.

4. Shaw E, Farris N, McNeil J, Friedenreich C. Obesity and Endometrial cancer. Recent Results Cancer Res 2016; 208: 107-36.

5. Werner HM, Trovik J, Marcickiewicz J, Tingulstad S, Staff AC, Amant F, et al. Revision of FIGO surgical staging in 2009 for endometrial cancer validates to improve risk stratification. Gynecol Oncol 2012; 125: 103-8.

6. Toptaş T, şimşek T, Karaveli \$̧. Prognostic risk factors for lymph node involvement in patients with endometrial cancer. Turk J Obstet Gynecol 2017; 14: 52-7.

7. Kang S, Nam JH, Bae DS, Kim JW, Kim MH, Chen X, et al. Preoperative assessment of lymph node metastasis in endometrial cancer: A Korean Gynecologic Oncology Group Study. Cancer 2017; 123: 263-72.

8. Tas EE, Yavuz AF. The prognostic significance of preoperative serum cancer antigen 15-3 levels in endometrial carcinomas. Saud Med J 2017; 38: 1096100.

9. Haldorsen IS, Salvesen HB. What is the best preoperative imaging for endometrial cancer? Curr Oncol Rep 2016; 18: 25.

10. Tschernichovsky R, Diver EJ, Schorge JO, Goodman A. The role of lymphadenectomy versus sentinel lymph node biopsy in early-stage endometrial cancer: a review of the literature. Am J Clin Oncol 2016; 39: 516-21.

11. Bodurtha Smith AJ, Fader AN, Tanner EJ. Sentinel lymph node assessment in endometrial cancer: a systemic review and meta-analysis. Am J Obstet Gynecol 2017; 216: 459-76.e10.

12. Practice Bulletin No. 149: Endometrial cancer. Obstet Gynecol 2015; 125 : 1006-26. 
13. Orr JW Jr, Taylor PT Jr. Surgical management of endometrial cancer: how much is enough? Gynecol Oncol 2008; 109: 1-3.

14. Creasman WT, Morrow CP, Bundy BN, Homesley HD, Graham JE, Heller PB. Surgical pathologic spread patterns of endometrial cancer. A Gynecologic Oncology Group Study. Cancer 1987; 60(8 Suppl): 2035-41.

15. Sari ME, Yalcin I, Sahin H, Meyanli NM, Gungor T. Risk factors for paraaortic lymph node metastasis in endometrial cancer. Int J Clin Oncol 2017; 22: 93744.

16. Guntupalli SR, Zighelboim I, Kizer NT, Zhang Q, Powell MA, Thaker PH, et al. Lymphovascular space invasion is an independent risk factor for nodal disease and poor outcomes in endometrioid endometrial cancer. Gynecol Oncol 2012; 124: 31-5.

17. Orr JW Jr, Taylor PT Jr. Surgical management of endometrial cancer: how much is enough? Gynecol Oncol 2008; 109: 1-3.

18. Benedet JL, Bender H, Jones H, Ngan HY, Pecoreli S. FIGO staging classifications and cinica guidelines in the management of gynecological cancers. FIGO Committee on Gynecologic Oncology.Int J Gynaecol Obstet 200; 70: 209-62.

19. Thomas MB, Marianai A, Cliby WA, Keeney GA, Podratz KC, Dowdy SC. Role of systemic lymphadenectomy and adjuvant therapy in stage I uterine papillary serous carcinoma. Gynecol Oncol 2017; 107: 186-9.

20. Pecorelli S. Revised FIGO staging for carcinoma of the vulva, cervix, and endometrium. Int J Gynaecol Obstet 2009; 105: 103-4.
21. Tejerizo-Garcia A, Jimenez-Lopez JS, Munoz-Gonzalez JL, Bartolome-Sotillos S, Margueta-Margues L, Lopez-Gonzalez G, et al. Overall survival and diseasefree survival in endometrial cancer:prognostic factors in 276 patients. Onco Targets Ther 2013; 9: 1305-13.

22. Frost JA, Webster KE, Bryant A, Morrison J. Lymphadenectomy for the managemet of endometrial cancer. Cochrane Database Syst Rev 2017; 10 : CD007585.

23. Stalberg K, Kjolhede P, Bjurberg M, Borgfeldt C, Dahm-Kahler P, Falconer H, et al. Risk factors for lymph node metastases in women with endometrial cancer: A population-based, nation-wide register study-On behalf of the Swedish Gynecological Cancer Group. Int J Cancer 2017; 140: 2693-700.

24. Jorge S, Hou JY, Tergas Al, Burke WM, Huang Y, Hu JC, et al. Magnitude of risk for nodal metastasis associated with lymphovascular space invasion for endometrial cancer. Gynecol Oncol 2016; 140: 387-93.

25. Mariani A, Webb MJ, Keeney GL, Haddock MG, Calori G, Podratz KC. Low-risk corpus cancer: is lymphadenectomy or radiotherapy necessary? Am J Obstet Gynecol 2000; 182: 1506-19.

26. Vergas R, Rauh-Hain JA, Clemmer J, Clark RM, Goodman A, Growdon WB, et al. Tumor size, depth of invasion, and histologic grade as prognostic factors of lymph node involvement in endometrial cancer: a SEER analysis. Gynecol Oncol 2014; 133: 216-20.

27. Cox Bauer CM, Greer DM, Kram J JF, Kamelle SA. Tumor diameter as a predictor of lymphatic dissemination in endometrioid endometrial cancer. Gynecol Oncol 2016; 141: 199-205. 